\title{
Uji Efektifitas Pertumbuhan Vegetatif Bunga Nusa Indah (Mussaenda Pubescens) Terhadap Pemberian ZPT Organik Jagung Muda Pada Berbagai Sumber Setek
}

\author{
Usmar Kaffi* \\ Program Studi Agroteknologi Fakultas Ilmu Pertanian Universitas Al Asyariah Mandar \\ usmar_kaffi@gmail.com
}

\begin{abstract}
Abstrak
Pengembangan tanaman hias di tanah air sangat dipengaruhi oleh metode bercocok tanam, olehnya itu faktor penting yang harus diperhatikan adalah meningkatkan pengetahuan serta keterampilan petani sehingga mereka mampu berusaha dengan maksimal serta memanfaatkan peluang seefisien mungkin. Salah satu jenis tanaman hias yang banyak diminati oleh masyarakat karena penampilannya yang menarik adalah bunga nusa indah (Mussaenda pubescens). Nusa indah merupakan salah satu tanaman hias yang banyak ditanam oleh masyarakat. Saat ini dikenal ada dua jenis bunga nusa indah yaitu warna orange dan putih. Salah satu permasalahan pada tanaman bunga Nusa Indah adalah perbanyakam yang sulit dilakukan. Salah satu upaya yang bisa dilakukan adalah penggunaan zat pengatur tumbuh dan sumber setek yang digunakan. Penelitian ini bertujuan mengetahui efektifitas petumbuhan vegetatif bunga nusa indah terhadap pemberian ekstrak jagung muda pada berbagai sumber setek. Penelitian menggunakan Rancangan Acak Kelompok dengan dua faktor yaitu Faktor J (Ekstrak Jagung) yang terdiri dari 3 taraf,yaitu tanpa ekstrak, ekstrak jagung manis dan ekstrak jagung pulut. Dan Faktor S (Sumber Setek) yang terdiri dari 3 taraf yaitu setek pangkal,setek tengah dan setek pucuk, diperoleh 9 kombinasi perlakuan dengan 3 ulangan sehingga diperoleh 27 unit perlakuan. Hasil penelitian menunjukan Interaksi antara ekstrak jagung pulut (J2) dan sumber setek tengah batang (S2) memberikan pengaruh terbaik pada parameter waktu muncul tunas. Pemberian ekstrak jagung pulut memberikan pengaruh terbaik terhadap parameter waktu muncul tunas, panjang tunas, jumlah daun dan panjang akar. Sumber setek tengah batang memberikan pengaruh terbaik pada parameter waktu muncul tunas dan panjang akar.
\end{abstract}

Kata Kunci : Efektifitas, Nusa Indah, Jagung Muda

\section{PENDAHULUAN}

Pengembangan tanaman hias di tanah air sangat dipengaruhi oleh metode bercocok tanam, olehnya itu faktor penting yang harus diperhatikan adalah meningkatkan pengetahuan serta keterampilan petani sehingga mereka mampu berusaha dengan maksimal serta memanfaatkan peluang seefisien mungkin (Desmaniar 2015).

Nusa indah adalah genus dari tumbuhan berbunga dalam familia Rubiaceae/kopi-kopian. Berasal dari Kongo,Afrika dan Asia tropis maupun subtropis, banyak terdapat di Florida tersebar kedaratan asia tenggara dan Cina beberapa spesiesnya ada yang dibudidayakan sebagai tanaman hias, musssaenda terdiri atas 200 spesies 10 diantaranya digunakan sebagai tanaman hias dan obat serta 3 diantaranya sebagai tanaman lanskap (McLaughlin John and Garofalo Joe 2004).

Zat pengatur tumbuh (ZPT) merupakan senyawa organik bukan hara yang mempengaruhi proses fisiologi suatu tanaman (Widyastuti dan Tjokrokusumo,2006) Zat pengatur tumbuh yang

Agrovital | Jurnal Ilmu Pertanian Universitas Al Asyariah bersumber dari bahan organik lebih bersifat ramah lingkungan, mudah didapat, aman digunakan, dan lebih murah.Seringkali pasokan zat pengatur tumbuh yang secara alami ada dalam tanaman berada di bawah optimal, sehingga dibutuhkan sumber dari luar untuk menghasilkan respon yang maksimal. Umumnya ZPT alami langsung tersedia di alam dan berasal dari bahan organik, contohnya air kelapa, urin sapi, dan ekstraksi dari bagian tanaman (Shahab et al. 2009; Zhao 2010)

Banyak orang menggunakan perbanyakan tanaman secara vegetatif agar memperoleh tanaman yang umur, jenis, dan sifatnya sama dengan induknya. Diduga bahan stek pada bagian batang (pangkal, tengah dan ujung) akan mempengaruhi pertumbuhan akar stek berkaitan dengan sistem trasnportasi fotosintat pada batang.Keberhasilan perbanyakan dengan cara setek ditandai oleh terjadinya regenerasi akar dan pucuk pada bahan stek sehingga menjadi tanaman baru (Widiarsih, et. al., 2008). 


\section{BAHAN DAN METODE}

Rancangan percobaan yang digunakan adalah Rancangan Acak Kelompok dengan dua faktor yaitu Faktor J (Ekstrak Jagung) yang terdiri dari 3 taraf,yaitu tanpa ekstrak, ekstrak jagung manis dan ekstrak jagung pulut. Dan Faktor S (Sumber Setek) yang terdiri dari 3 taraf yaitu setek pangkal,setek tengah dan setek pucuk, diperoleh 9 kombinasi perlakuan dengan 3 ulangan sehingga diperoleh 27 unit perlakuan.

\section{HASIL DAN PEMBAHASAN}

\section{a. Waktu muncul tunas}

Pemberian ekstrak jagung muda (J) berpengaruh sangat nyata dan sumber setek (S) memperlihatkan pengaruh nyata, begitu pula interaksinya $(\mathrm{J} \times \mathrm{S})$ memperlihatkan pengaruh sangat nyata terhadap waktu munculnya tunas bunga nusa indah dapat dilihat pada tabel 1

Tabel 1.Rata-rata Waktu Muncul Tunas (hari) pada pemberian Ekstrak Jagung Muda dan Sumber Setek Terhadap Pertumbuhan Vegetatif Bunga Nusa Indah.

\begin{tabular}{|c|c|c|c|c|c|}
\hline \multirow{2}{*}{$\begin{array}{c}\text { Ekstrak } \\
\text { jagung } \\
\text { muda }\end{array}$} & \multicolumn{3}{|c|}{ Sumber stek } & \multirow{2}{*}{$\begin{array}{l}\text { Rata- } \\
\text { rata }\end{array}$} & \multirow{2}{*}{$\begin{array}{c}\text { NP. } \\
\text { UJBD } \\
\alpha 0,01\end{array}$} \\
\hline & $\mathrm{S} 1$ & $\mathrm{~S} 2$ & $\mathrm{~S} 3$ & & \\
\hline $\mathrm{J} 1$ & $7,50^{\mathrm{ax}}$ & $8,00^{\mathrm{ax}}$ & $8,17^{\mathrm{ax}}$ & 7,89 & 1,56 \\
\hline $\mathrm{J} 2$ & $8,50^{\mathrm{ax}}$ & $8,00^{\mathrm{ax}}$ & $8,00^{\mathrm{ax}}$ & 8,17 & 1,65 \\
\hline $\mathrm{J} 3$ & $7,83^{\mathrm{ax}}$ & $5,00^{\text {by }}$ & $7,67^{\mathrm{az}}$ & 6,83 & \\
\hline $\begin{array}{c}\text { Rata- } \\
\text { rata }\end{array}$ & 7,94 & 7,00 & 7,95 & & \\
\hline $\begin{array}{c}\text { NP. } \\
\text { UJBD } \alpha \\
0,01\end{array}$ & 1,56 & 1,65 & & & \\
\hline
\end{tabular}

Keterangan : Angka-angka yang diikuti oleh huruf yang tidak sama berarti berbeda nyata pada Uji Jarak Berganda Duncan Taraf $\alpha 0,01$

Berdasarkan uji UJBD taraf $\alpha 0,01$ pada Tabel 1 , memperlihatkan bahwa interaksi antar pemberian ekstrak jagung pulut dengan suber setek tengah (J2 X S2) memberikan pengaruh baik dan berbeda nyata dibandingkan dengan yang lainnya terhadap waktu munculnya tunas.

\section{b. Panjang tunas}

Sidik ragam menunjukkan bahwa pemberian ekstrak jagung muda (J) berpengaruh sangat nyata dan sumber setek (S) memperlihatkan pengaruh nyata, sedangkan interaksinya ( $\mathrm{J}$ S) memperlihatkan pengaruh tidak nyata terhadap panjang tunas bunga nusa indah.

Tabel 2. Rata-rata Panjang Tunas (cm) pada pemberian Ekstrak Jagung Muda dan Sumber Setek Terhadap Pertumbuhan Vegetatif Bunga Nusa Indah.

\begin{tabular}{cccccc}
\hline \multirow{2}{*}{$\begin{array}{l}\text { Ekstrak } \\
\text { jagung } \\
\text { muda }\end{array}$} & \multicolumn{2}{l}{ Sumber stek } & & & \multicolumn{2}{l}{ NP. } \\
\cline { 2 - 5 } Rata- & $\begin{array}{l}\text { UJBD } \\
\text { rata } 0,01\end{array}$ & \\
\hline J1 & 6,83 & 9,97 & 7,00 & $7,93^{\mathrm{a}}$ & 2,12 \\
$\mathrm{~J} 2$ & 10,07 & 11,67 & 11,43 & $11,06^{\mathrm{b}}$ & 2,22 \\
$\mathrm{~J} 3$ & 11,10 & 11,97 & 11,20 & $11,42^{\mathrm{b}}$ & \\
Rata- & $9,33^{\mathrm{a}}$ & $11,20^{\mathrm{b}}$ & $9,88^{\mathrm{b}}$ & & \\
rata & & & & & \\
NP. & 1,53 & 1,61 & & & \\
$\begin{array}{c}\text { UJBD } \\
\alpha 0,01\end{array}$ & & & & & \\
\hline
\end{tabular}

Keterangan : Angka-angka yang diikuti oleh huruf yang tidak sama berarti berbeda nyata pada Uji Jarak Berganda Duncan Taraf $\alpha$ 0,01

Berdasarkan uji UJBD taraf $\alpha 0,01$ pada Tabel 2 , memperlihatkan bahwa pemberian ekstrak jagung jenis pulut (J2) pengaruhnya lebih baik dan berbeda nyata dibandingkan tanpa pemberian ekstrak jagung (J0), tapi tidak berbeda dengan pemberian ekstrak jagung manis (J1)). Berdasarkan UJBD taraf $\alpha 0,05$ pada Tabel 2 penggunaan sumber setek tengah batang (S2) memberikan pengaruh baik tapi tidak berbeda nyata dibandingkan dengan sumber setek pangkal batang (S1) dan sumber setek pucuk batang (S3).

c. Jumlah daun

Pemberian ekstrak jagung muda (J) berpengaruh sangat nyata dan sumber setek (S) memperlihatkan pengaruh tidak nyata, dan interaksinya ( $J$ x $\quad S$ ) memperlihatkan pengaruh yang tidak nyata pada parameter jumlah daun dapat dilihat pada tabel 3 
Tabel 3. Rata-rata Jumlah Daun (helai) pada pemberian Ekstrak Jagung Muda dan Sumber Setek Terhadap Pertumbuhan Vegetatif Bunga Nusa Indah.

\begin{tabular}{|c|c|c|c|c|c|}
\hline \multirow{2}{*}{$\begin{array}{l}\text { Ekstrak } \\
\text { jagung } \\
\text { muda }\end{array}$} & \multicolumn{3}{|c|}{ Sumber stek } & \multirow{2}{*}{$\begin{array}{l}\text { Rata- } \\
\text { rata }\end{array}$} & \multirow{2}{*}{$\begin{array}{l}\text { NP. } \\
\text { UJBD } \\
\alpha 0,01\end{array}$} \\
\hline & S1 & S2 & S3 & & \\
\hline $\mathrm{J} 1$ & 8,00 & 8,67 & 8,00 & $8,22^{\mathrm{a}}$ & 2,40 \\
\hline $\mathrm{J} 2$ & 10,00 & 11,67 & 11,33 & $11,00^{\mathrm{b}}$ & 2,53 \\
\hline $\mathrm{J} 3$ & 11,67 & 12,67 & 11,67 & $12,00^{\mathrm{b}}$ & \\
\hline $\begin{array}{l}\text { Rata- } \\
\text { rata }\end{array}$ & 9,89 & 11,00 & 10,33 & & \\
\hline
\end{tabular}

Keterangan : - Angka-angka yang diikuti oleh huruf yang tidak sama berarti berbeda nyata pada Uji Jarak Berganda Duncan Taraf $\alpha 0,01$

Berdasarkan uji UJBD taraf $\alpha 0,01$ pada Tabel 3 , memperlihatkan bahwa pemberian ekstrak jagung jenis pulut (J2) pengaruhnya lebih baik dan berbeda nyata dibandingkan tanpa pemberian ekstrak jagung (J0), tapi tidak berbeda dengan pemberian ektrak jagung manis (J1).

\section{d. Persentase tumbuh}

Pemberian ekstrak jagung muda (J) dan sumber setek (S) memperlihatkan pengaruh tidak nyata, begitupun interaksinya ( $\left.\begin{array}{lll}\mathrm{J} & \mathrm{X} & \mathrm{S}\end{array}\right)$ memperlihatkan pengaruh yang tidak nyata dapat dilihat pada gambar 1

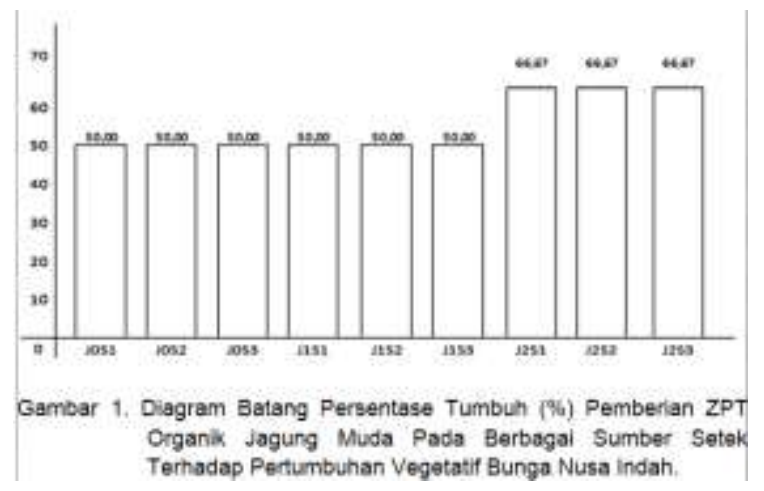

Gambar 1, memperlihatkan bahwa pemberian ekstrak jagung pulut pada ketiga sumber setek tersebut yaitu pangkal, tengah dan ujung/pucuk memiliki niai rata-rata persentase tumbuh terbesar

\section{e. Panjang akar}

Pemberian ekstrak jagung muda (J) memperlihatkan pengaruh sangat nyata, dan sumber setek (S) memperlihatkan pengaruh nyata, namun interaksinya (J x S) memperlihatkan pengaruh yang tidak nyata pada panjang akar dapat dilihat pada tabel 4

Tabel 4. Rata-rata Panjang Akar (cm) pada pemberian Ekstrak Jagung Muda dan Sumber Setek Terhadap Pertumbuhan Vegetatif Bunga Nusa Indah.

\begin{tabular}{|c|c|c|c|c|c|}
\hline \multirow{2}{*}{$\begin{array}{l}\text { Ekstrak } \\
\text { jagung } \\
\text { muda }\end{array}$} & \multicolumn{3}{|c|}{ Sumber stek } & \multirow{2}{*}{$\begin{array}{l}\text { Rata- } \\
\text { rata }\end{array}$} & \multirow{2}{*}{$\begin{array}{l}\text { NP. } \\
\text { UJBD } \\
\alpha 0,01\end{array}$} \\
\hline & $\mathrm{S} 1$ & $\mathrm{~S} 2$ & $\mathrm{~S} 3$ & & \\
\hline $\mathrm{J} 1$ & $7,03^{\mathrm{ax}}$ & $7,07^{\mathrm{ax}}$ & $7,17^{\mathrm{ax}}$ & 7,09 & 0,83 \\
\hline $\mathrm{J} 2$ & $7,69^{\mathrm{abx}}$ & $8,23^{b x}$ & $8,00^{\mathrm{ax}}$ & 7,94 & 0,87 \\
\hline $\mathrm{J} 3$ & $7,92^{\text {bx }}$ & $8,72^{\text {by }}$ & $7,90^{\mathrm{az}}$ & 8,18 & \\
\hline $\begin{array}{l}\text { Rata- } \\
\text { rata }\end{array}$ & 7,52 & 8,01 & 7,69 & & \\
\hline $\begin{array}{l}\text { NP. } \\
\text { UJBD } \\
\alpha 0,01\end{array}$ & 0,60 & 0,63 & & & \\
\hline
\end{tabular}

Keterangan : Angka-angka yang diikuti oleh huruf yang tidak sama berarti berbeda nyata pada Uji Jarak Berganda Duncan Taraf $\alpha 0,01$

Berdasarkan uji UJBD taraf $\alpha 0,01$ pada Tabel 4, memperlihatkan bahwa pemberian ekstrak jagung jenis pulut (J2) pengaruhnya lebih baik dan berbeda nyata dibandingkan tanpa pemberian ekstrak jagung (J0) tapi tidak berbeda dengan pemberian ektrak jagung manis (J1). Sedangkan JBD taraf $\alpha 0,05$ Sumber setek tengah batang (S2) penaruhnya lebih baik tapi tidak berbeda nyata dengan sumber setek pangkal batang (S1) dan sumber setek pucuk batang (S3).

\section{HASIL DAN PEMBAHASAN}

\section{Waktu Muncul Tunaas}

Hasil penelitian yang telah dilakukan menunjukkan bahwa interaksi antara ekstrak jagung pulut (J2) dan sumber setek tengah batang (S2) memberikan pengaruh nyata terhadap waktu muncul tunas hal ini diduga bahwa selain kandungan hormon tumbuh pada ekstrak jagung tersebut, dugaan lain bahwa kandungan karbohidrat pada jagung pulut lebih tinggi dibandingkan dengan jagung manis, hal 
ini dinyatakan dalam Widowati et al.,(2005) bahwa jagung pulut atau ketan mengandung karbohidrat sebesar (72,81 gr), sedangkan jagung manis (69,3 gr). Dengan demikian pada kondisi optimum karbohidrat akan berintegrasi dengan bahan pembangun lainnya. dengan adanya penumpukan cadangan makanan terutama persediaan karbohidrat sangat berpengaruh sekali terhadap muncul tunas (Alkori et al., 2016).Setek bagian tengah batang diduga merupakan umur yang sesuai untuk dijadikan bahan setek, Kondisi fisiologis tanaman yang mempengaruhi penyetekan adalah umur bahan stek, jenis tanaman, adanya tunas dan daun muda pada stek, persediaan bahan makanan, dan zat pengatur tumbuh (Zong et al.,2008).

Menurut Djamhuri (2011) cadangan karbohidrat pada tanaman yang merupakan hasil dari keseimbangan proses respirasi dan fotosintesis, perombakannya dapat dikurangi karena tidak ada pembungaan, sehingga memungkinkan tanaman mengakumulasi cadangan makanan

\section{Panjang Tunas}

Pemberian ekstrak jagung pulut (J2) dan penggunaan sumber setek bagian tengah batang (S2) memberikan pengaruh nyata pada parameter panjang tunas, hal ini diduga bahwa pada saat perendaman setek ekstrak jagung pulut mampu menambah cadangan makanan pada bahan setek tengah batang yang merupakan ukuran setek yang sesuai untuk dijadikan bahan setek, Adanya pengaruh nyata ukuran diameter stek terhadap panjang tunas dan diameter tunas disebabkan oleh banyaknya jumlah ketersediaan cadangan makanan pada batang stek yang dapat dipakai oleh stek sebagai sumber energi untuk pembentukan akar sehingga tunas dapat tumbuh dengan optimum dimana ukuran diameter batang stek berbanding lurus dengan banyaknya jumlah cadangan makanan yang tersedia. Tidak adanya akar pada stek diawal penanaman memaksa stek memanfaatkan sumber cadangan dari batang (Haryati et al.,2014)

\section{Jumlah Daun}

Hasil Parameter jumlah daun menunjukkan penggunaan ekstrak jagung pulut (S2) meberikan pengaruh nyata dibandingan yang lainnya,hal ini diduga bahwa kandungan sitokinin pada jagung pulut mampu mendorong pemecahan sel. Menurut Marpaung dan Hutabarat (2015) bahwa kandungan sitokinin dalam suatu bahan dapat merangsang sel-sel untuk pembentukan daun, selanjutnya dikemukakan oleh Wulandari et al.,(2013) bahwa sitokinin mampu memacu pembelahan sel pada primordia daun yang mendukung bertambahnya jumlah daun pada setek. Dugaan lain bahwa kandungan protein dari ekstrak jagung pulut mampu menyusun terbentuknya daun, hal ini didukung oleh pernyataan Hartati (2009) bahwa protein merupakan senyawa yang membantu dalam penyusunan daun. Lebih lanjut dikemukakan oleh Seswita (2010), bahwa komponen - komponen yang terkandung didalam ekstrak jagung muda dapat berintegrasi dengan hormon endogen yang dimiliki oleh setek sehingga mampu merangsang pembelahan sel.

\section{Panjang Akar}

Pemberian ekstrak jagung pulut (J2) menunjukkan pengaruh nyata pada parameter panjang akar ha ini diduga saat perendaman bahan setek zatzat yang terkandung dalam setek bertambah dan mampu berinteraksi dengan auksin yang dikandung secara endogen oleh setek tersebut, hal ini dikemukakan oleh Budi et al.,(2012) bahwa pembentukan akar terjadi karena adanya pergerakan ke bawah dari auksin, karbohidrat dan zat-zat yang berinteraksi dengan auksin (rooting cofaktor) yang mengakibatkan perakaran, baik yang berasal dari tunas maupun dari daun. Lebih jauh Djamhuri (2011) mengemukakan bahwa zat-zat tersebut akan mengumpul di dasar setek yang selanjutnya akan menstimulir pembentukan akar auksin alami yang didapat dari ekstrak jagung sudah memberikan hasil yang optimal terhadap munculnya akar (Hartati 2009). Hal serupa dikemukakan oleh Damiska et al.,(2015) bahwa ekstrak jagung muda mengandung asam amino, karbohidrat, vitamin, mineral, serta zat pengatur tumbuh auksin dan sitokinin yang dapat memenuhi unsur-unsur hara yang diperlukan oleh tanaman.

\section{KESIMPULAN}

1. Interaksi antara ekstrak jagung pulut (J2) dan sumber setek tengah batang (S2) memberikan pengaruh terbaik pada parameter waktu muncul tunas.

2. Pemberian ekstrak jagung pulut memberikan pengaruh terbaik terhadap parameter waktu muncul tunas, panjang tunas, jumlah daun dan panjang akar. 
3. Sumber setek tengah batang memberikan pengaruh terbaik pada parameter waktu muncul tunas dan panjang akar

\section{DAFTAR PUSTAKA}

Alkori, Marpaung.R, dan Nengsih Yulistiati, (2016) Sulur Panjat Merupakan Sumber Setek Terbaik untuk Perbanyakan Bibit Lada Secara Vegetatif.Jurnal Media Pertanian Vol. 1 No. 1 Tahun 2016 Hal. 29 - 35, Universitas Batanghari.

Budi, M.A.I. Donowati dan Dianto (2012) Pengaruh kencing sapi dan air kelapa muda pada pertumbuhan stek lada (Piper nigrum, L.) Jurnal Java Primordial Volume 8, Nomor 1, April 2012.

Haryati, Ginting.J, Panjaitan.LRH,(2014). Respons Pertumbuhan Berbagai Ukuran Diameter Batang Stek Bugenvil (Bougainvillea spectabilisWilld.) Terhadap Pemberian Zat Pengatur Tumbuh.Jurnal Online Agroekoteknologi, Vol.2, No.4 : 1384 - 1390, Universitas Sumatera Utara.

McLaughlin John and Garofalo Joe (2004), Mussaenda For south Florida Landscapes. Factsheet No. 82. University of Florida.

Marpaung,AE dan Hutabarat,RC.(2015) Respons Jenis Perangsang Tumbuh Berbahan Alami dan Asal Setek Batang Terhadap Pertumbuhan Bibit Tin (Ficus carica L.) (The Response of Natural Growing Stimulant Materials and Stem Cutting Origin to the Growth of Fig Seedling). J.Hort,Vol 25 (1) :37-43

Agrovital | Jurnal Ilmu Pertanian Universitas Al Asyariah
Mashudi (2013), 'Pengaruh provenan dan komposisi media terhadap keberhasilan teknik penunasan pada setek pucuk pulai darat', Jurnal Penelitian Hutan Tanaman, vol. 10, no.1, pp. 25-32.

Seswita, D. (2010). Penggunaan Aplikasi Air Kelapa sebagai Zat Pengatur Tumbuh pada Mustipikasi Tunas Temulawak (Curcuma xanthorrbisa Roxb). In vitro. Jurnal Vol 16, No 4 (2010).

Shahab S, Ahmed N, Khan NS. (2009). Indole acetic acid production and enhanced plant growth promotion by indigenous PSBs. African Jurnal.Agric Res 4: 1312-1316.

Widiarsih, S., Minarsih, Dzurrahmah, B. Wirawan dan W. B. Suwarno. (2008). Perbanyakan Tanaman Secara Vegetatif Buatan.

Widowati, S., B.A. S. Santosa, dan Suarni. 2005. Mutu gizi dan sifat fungsional jagung. Prosiding Seminar dan Lokakarya Nasional Jagung. Pusat Penelitian dan Pengembangan Tanaman Pangan. Makassar, 29-30 September 2005. p. 343-350.

Widyastuti N, Tjokrokusumo D. (2006). Peranan beberapa Zat Pengatur Tumbuh (ZPT) tanaman pada kultur in vitro. Jurnal Sains dan Teknologi BPPT 3 (5): 55-63.

Wulandari, RC, Riza Linda, L \& Mukarlina (2013), Pertumbuhan setek melati putih (Jasminum sambac (L) W. Ait.) dengan pemberian air kelapa dan IBA (indole butyricacid)', Jurnal Protobiont., vol. 2, no. 2, hlm. 39-43.

Zhao Y. (2010). Auxin biosynthesis and its role in plant development. Ann Rev Plant Biol 61: 4964.

Zong M. C., Yi Li and Zhen Z. (2008). Plant Growth Regulators Used in Propagation. CRC Press. Boca Raton, Florida. 